\title{
Evaluasi dan Manajemen Parkir Kawasan Tanrise City Jember
}

\author{
Dwi Sartika $^{1}$, Willy Kriswardhana ${ }^{2}$, Hernu Suyoso ${ }^{3}$ \\ 12,3Jurusan Teknik Sipil, Fakultas Teknik, Universitas Jember
}

\begin{abstract}
Abstrak
Parkir merupakan fasilitas yang harus terpenuhi dalam setiap perencanaan pembangunan. Perencanaan parkir dilakukan pada pembangunan yang berskala besar maupun kecil, seperti pembangunan Kawasan Superblok Tanrise City Jember yang merupakan pembangunan berskala besar karena menggabungkan beberapa bangunan dalam satu kawasan. Perencanaan pembangunan terdapat perencanaan ruang parkir kendaraan, sehingga evaluasi kebutuhan ruang parkir perlu dilakukan. Evaluasi perencanaan ruang parkir dilakukan dengan analisa data bangkitan tarikan kendaraan dari beberapa bangunan pembanding. Penelitian menggunakan metode perbandingan dengan menggunakan data bangkitan tarikan kendaraan sebagai variabel. Selain itu, penelitian ini menggunakan Pedoman Teknis Penyelenggaraan Parkir sebagai acuan untuk memanajemen ruang parkir. Setelah dilakukan perhitungan kinerja parkir diketahui terdapat beberapa bangunan yang tidak mampu memenuhi permintaan parkir dengan IP $>1$. Kemudian, untuk mengoptimalkan ruang parkir yang tidak mencukupi diadakan perluasan lahan parkir, solusi lain yang dapat dilakukan adalah dengan pengalihan ruang parkir. Berdasarkan manajemen yang dilakukan, pengalihan ruang parkir dapat mengatasi permintaan parkir berarti manajemen ruang parkir tersebut dapat direkomendasikan dan layak untuk diterapkan di lapangan.
\end{abstract}

Kata kunci : Bangkitan tarikan, Evaluasi, Manajemen ruang parkir, Ruang parkir.

\section{Pendahuluan}

Ketersediaan ruang parkir merupakan fasilitas wajib bagi kendaraan yang harus terpenuhi dalam setiap pembangunan. Adanya fasilitas ruang parkir kendaraan menjadi bagian penting dalam perencanaan sebuah pembangunan. Sebuah penelitian yang dilakukan oleh Mitchell (2015) berkaitan dengan self-driving cars dalam World Economic Forum menyebutkan bahwa ruang parkir merupakan unsur penting dalam perencanaan transportasi karena rata-rata $95 \%$ kendaraan berada pada tempat parkir sepanjang usia rencana kendaraan. Oleh karena itu, ruang parkir yang memiliki sistem tertata serta manajemen yang baik dapat menjadikan pengguna atau pengunjung merasa lebih nyaman. Kemudian, perencanaan ruang parkir tidak hanya dilakukan pada pembangunan berskala kecil, tetapi juga dilakukan pada pembangunan yang berskala besar. Salah satu pembangunan yang memiliki skala besar adalah pembangunan Kawasan Superblok Tanrise City jember.

Tanrise City jember direncanakan sebuah pembangunan Kawasan Superblok yang menggabungkan hotel, mall, ruko, depo bangunan, convention hall dan apartemen dalam satu kawasan. Pembangunan tersebut tentu menjadi alasan diadakannya perencanaan ruang parkir yang luas dan memadai sebagai penunjang sarana dan prasarana pada Tanrise City Jember. Perencanaan ruang parkir yang memadai dimaksudkan berkaitan dengan desain serta manajemen penempatan ruang parkir yang mudah serta mampu menampung banyak kendaraan. Sebuah penelitian oleh Gallivan (2011) menyebutkan bahwa rata-rata pengemudi pada 20 Corresponding author.: Willy Kriswardhana E-mail addresses: willy.teknik@unej.ac.id kota di dunia memerlukan waktu hingga 20 menit untuk menemukan tempat parkir. Kemudian Pel dan Chaniotakis (2017) dalam penelitiannya menyebutkan sebuah penangan dari masalah tersebut dengan melakukan pemodelan perilaku pencarian, sedangkan Lei dan Ouyang (2017) menyebutkan solusi lain dalam penelitiannya yaitu dengan melakukan pengembangan model dengan menetapkan ruang parkir untuk kendaraan secara optimal. Kemudian dalam penelitian SHAO et al., (2008) disebutkan satu solusi lain yaitu dengan berfokus pada penempatan tata letak fasilitas ruang parkir, selain itu Zips et al., (2016) dalam penelitiannya menyebutkan solusi yaitu dengan mengoptimalkan jalur sirkulasi dengan membagi menjadi 2 bagian yaitu satu bagian untuk tempat parkir dan satu bagian lainnya digunakan sebagai jalur sirkulasi.

Penelitian pada Kawasan Tanrise City Jember perlu dilakukan untuk mengevaluasi perencanaan ruang parkir untuk dapat menghasilkan manajemen yang baik terkait optimalisasi serta kenyamanan pengguna ruang parkir Tanrise City jember.

\section{Metode Penelitian}

Pengidentifikasian masalah dalam penelitian ini berdasarkan pada studi literatur yang berkaitan dengan topik penelitian. Studi literatur dapat berupa buku-buku, artikel, jurnal dengan topik yang sesuai dengan penelitian, serta beberapa peraturan terkait dengan penelitian.

\subsection{Lokasi Penelitian}


Penelitian dilakukan pada lokasi pembangunan Kawasan Superblok Tanrise City Jember yang terletak di Jl. Hayam Wuruk, Mrapa, Sempusari, Kecamatan Kaliwates, Kabupaten Jember.

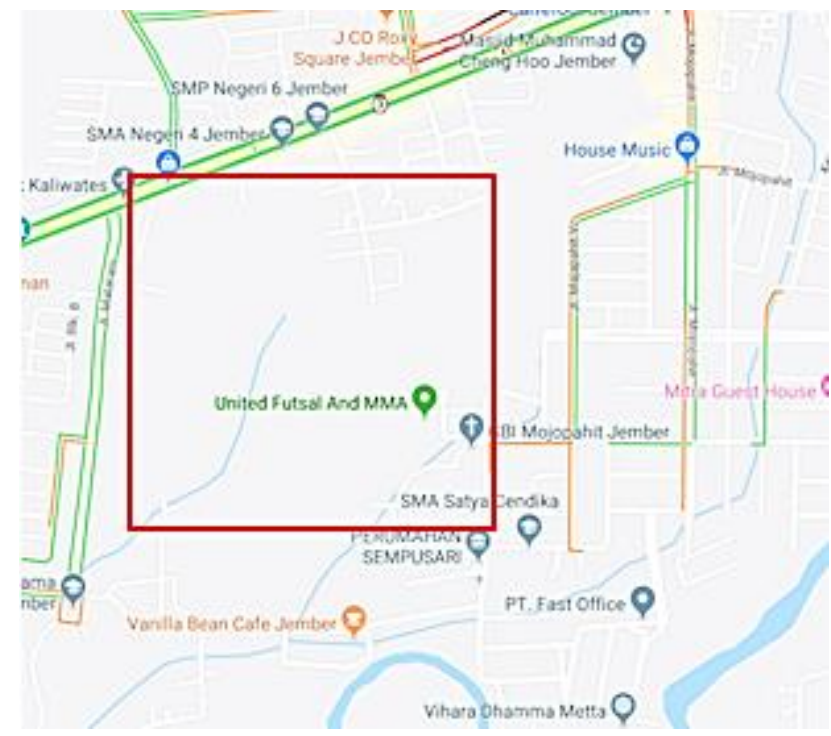

Sumber: Google Maps (2019)

Gambar 1. Lokasi pembangunan Tanrise City Jember

\subsection{Metode Pengumpulan Data}

Data yang dibutuhkan dalam penelitian ini diantaranya adalah data primer dan data sekunder. Data primer berupa data bangkitan dan tarikan kendaraan yang diperoleh dari survei kendaraan masuk dan keluar pada beberapa bangunan pembanding. Kemudian, data sekunder berupa data yang diperoleh dari instansi terkait (Pihak Tanrise City Jember) yaitu site plan Tanrise City Jember, denah bangunan, informasi masa konstruksi, dan sarana prasarana yang tersedia seperti jumlah lots parkir rencana.

\subsection{Pengolahan Data}

Data yang diperoleh dari survei di lapangan berupa data kendaraan masuk dan keluar kemudian diolah dengan menggunakan metode perbandingan. Metode ini menggunakan dua variabel diantaranya, variabel terikat yang berasal dari data bangkitan dan tarikan kendaraan pada bangunan pembanding dan variabel bebas yang berasal dari data luas lahan, luas bangunan, luas lahan parkir, jumlah lots parkir rencana, dan sarana prasarana yang tersedia pada tiap-tiap bangunan. Pengolahan dan perhitungan data menggunakan program bantu Microsoft Excel.

\subsection{Analisis Perhitungan}

Setelah dilakukan perhitungan dengan metode perbandingan tersebut, selanjutnya hasil perhitungan dianalisis menggunakan Parkir Pedoman Teknis Penyelenggaraan Fasilitas Parkir berdasarkan kinerja parkir serta persyaratan SRP. Manajemen yang dilakukan bertujuan untuk mengoptimalkan ruang parkir serta mendapatkan ruang parkir yang dapat menampung banyak kendaraan namun tetap dalam kaidah peraturan yang telah ditetapkan dalam SRP.

\section{Hasil dan Pembahasan}

Pada bagian ini, dijelaskan hasil penelitian dan pada saat yang sama diberikan pembahasan yang komprehensif. Hasil dapat disajikan dalam angka, grafik, tabel dan lain-lain yang membuat pembaca memahami dengan mudah. Pembahasan dapat dibuat dalam beberapa sub-bab.

\subsection{Bangkitan dan Tarikan Kendaraan}

Data bangkitan tarikan kendaraan diperoleh dari survei terhadap kendaraan masuk dan keluar bangunan pembanding. Data berupa kendaraan masuk dan keluar tersebut diinput pada program bantu Microsoft Excel yang kemudian dilakukan perhitungan dengan metode perbandingan dan diperoleh hasil bangkitan tarikan setiap bangunan pada Tanrise City Jember sebagai berikut.

Berdasarkan tabel 1 sampai dengan tabel 6 merupakan hasil perhitungan terhadap bangkitan dan tarikan kendaraan pada masing-masing bangunan di kawasan Tanrise City Jember yang dijadikan sebagai objek penelitian. Tabel 1 sampai dengan tabel 6 memperlihatkan data berupa empat jam puncak kecuali untuk ruko dan apartemen yang hanya terdapat 3 jam puncak. Bangkitan tarikan maksimum yang terjadi pada hotel di tabel 1 adalah sebanyak 265 kendaraan per jam, untuk mall di tabel 2 adalah 108 kendaraan, kemudian ruko di tabel 3 adalah 48 kendaraan, depo bangunan pada tabel 4 adalah 86 kendaraan, convention hall di tabel 5 adalah 118 kendaraan, dan apartemen pada tabel 6 adalah 50 kendaraan. Rata-rata jumlah maksimum bangkitan dan tarikan kendaraan terjadi pada akhir pekan (weekend).

Tabel 1. Bangkitan dan Tarikan Hotel Tanrise City Jember

\begin{tabular}{|c|c|c|c|c|c|c|c|c|c|c|c|}
\hline \multicolumn{7}{|c|}{ Weekday } & \multicolumn{5}{|c|}{ Weekend } \\
\hline \multirow{2}{*}{\multicolumn{2}{|c|}{$\begin{array}{c}\text { Periode Jam } \\
\text { Puncak }\end{array}$}} & \multicolumn{2}{|c|}{ Tarikan } & \multicolumn{2}{|c|}{ Bangkitan } & \multirow{2}{*}{ TOTAL } & \multicolumn{2}{|c|}{ Tarikan } & \multicolumn{2}{|c|}{ Bangkitan } & \multirow{2}{*}{ TOTAL } \\
\hline & & MC & $\mathbf{L V}$ & MC & $\mathbf{L V}$ & & MC & $\mathbf{L V}$ & MC & $\mathbf{L V}$ & \\
\hline 09.00 & - 10.00 & 17 & 3 & 3 & 3 & 26 & 31 & 31 & 23 & 57 & 142 \\
\hline 12.00 & - 13.00 & 6 & 3 & 9 & 3 & 21 & 68 & 9 & 46 & 46 & 169 \\
\hline
\end{tabular}




\begin{tabular}{|c|c|c|c|c|c|c|c|c|c|c|c|c|}
\hline \multicolumn{8}{|c|}{ Weekday } & \multicolumn{5}{|c|}{ Weekend } \\
\hline \multirow{2}{*}{\multicolumn{3}{|c|}{$\begin{array}{l}\text { Periode Jam } \\
\text { Puncak }\end{array}$}} & \multicolumn{2}{|c|}{ Tarikan } & \multicolumn{2}{|c|}{ Bangkitan } & \multirow{3}{*}{$\begin{array}{c}\text { TOTAL } \\
80\end{array}$} & \multicolumn{2}{|c|}{ Tarikan } & \multicolumn{2}{|c|}{ Bangkitan } & \multirow{3}{*}{$\begin{array}{c}\text { TOTAL } \\
262\end{array}$} \\
\hline & & & MC & $\mathbf{L V}$ & MC & $\mathbf{L V}$ & & MC & $\mathbf{L V}$ & MC & $\mathbf{L V}$ & \\
\hline 15.00 & 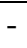 & 16.00 & 23 & 9 & 34 & 14 & & 77 & 51 & 91 & 43 & \\
\hline 18.00 & - & 19.00 & 3 & 11 & 3 & 3 & 20 & 26 & 26 & 37 & 63 & 152 \\
\hline
\end{tabular}

Tabel 2. Bangkitan dan Tarikan Mall Tanrise City Jember

\begin{tabular}{|c|c|c|c|c|c|c|c|c|c|c|c|c|}
\hline \multicolumn{8}{|c|}{ Weekday } & \multicolumn{5}{|c|}{ Weekend } \\
\hline \multirow{2}{*}{\multicolumn{3}{|c|}{$\begin{array}{c}\text { Periode Jam } \\
\text { Puncak }\end{array}$}} & \multicolumn{2}{|c|}{ Tarikan } & \multicolumn{2}{|c|}{ Bangkitan } & \multirow{3}{*}{$\begin{array}{c}\text { TOTAL } \\
30\end{array}$} & \multicolumn{2}{|c|}{ Tarikan } & \multicolumn{2}{|c|}{ Bangkitan } & \multirow{3}{*}{$\begin{array}{c}\text { TOTAL } \\
49\end{array}$} \\
\hline & & & \multirow{2}{*}{$\begin{array}{c}\mathbf{M C} \\
11\end{array}$} & \multirow{2}{*}{$\begin{array}{r}\mathbf{L V} \\
11\end{array}$} & \multirow{2}{*}{$\begin{array}{c}\text { MC } \\
3\end{array}$} & \multirow{2}{*}{$\begin{array}{c}\mathbf{L V} \\
5\end{array}$} & & \multirow{2}{*}{$\begin{array}{c}\text { MC } \\
26\end{array}$} & \multirow{2}{*}{$\begin{array}{r}\mathbf{L V} \\
15\end{array}$} & \multirow{2}{*}{$\begin{array}{c}\text { MC } \\
5\end{array}$} & \multirow{2}{*}{$\begin{array}{r}\mathbf{L V} \\
3\end{array}$} & \\
\hline $9: 30$ & 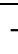 & $10: 30$ & & & & & & & & & & \\
\hline $13: 30$ & & $14: 30$ & 21 & 11 & 19 & 15 & 66 & 28 & 28 & 21 & 31 & 108 \\
\hline $14: 30$ & . & $15: 30$ & 12 & 18 & 10 & 18 & 58 & 18 & 34 & 24 & 30 & 106 \\
\hline $18: 30$ & - & $19: 30$ & 21 & 13 & 22 & 22 & 78 & 6 & 20 & 39 & 55 & 120 \\
\hline
\end{tabular}

Tabel 3. Bangkitan dan Tarikan Ruko Tanrise City Jember

\begin{tabular}{|c|c|c|c|c|c|c|c|c|c|c|c|c|}
\hline \multicolumn{8}{|c|}{ Weekday } & \multicolumn{5}{|c|}{ Weekend } \\
\hline \multirow{2}{*}{\multicolumn{3}{|c|}{ Waktu }} & \multicolumn{2}{|c|}{ Tarikan } & \multicolumn{2}{|c|}{ Bangkitan } & \multirow{2}{*}{ TOTAL } & \multicolumn{2}{|c|}{ Tarikan } & \multicolumn{2}{|c|}{ Bangkitan } & \multirow{2}{*}{ TOTAL } \\
\hline & & & MC & $\mathbf{L V}$ & MC & $\mathbf{L V}$ & & MC & LV & MC & $\mathbf{L V}$ & \\
\hline $7: 00$ & - & $8: 00$ & 43 & 3 & 2 & 0 & 48 & 23 & 1 & 2 & 0 & 26 \\
\hline $13: 00$ & - & $14: 00$ & 9 & 0 & 5 & 0 & 14 & 8 & 0 & 3 & 0 & 11 \\
\hline $16: 00$ & - & $17: 00$ & 13 & 0 & 6 & 1 & 20 & 1 & 0 & 11 & 4 & 16 \\
\hline
\end{tabular}

Tabel 4. Bangkitan dan Tarikan Depo Bangunan Tanrise City Jember Weekday

\section{Weekend}

\begin{tabular}{|c|c|c|c|c|c|c|c|c|c|c|c|c|c|c|c|c|}
\hline \multirow{2}{*}{\multicolumn{3}{|c|}{$\begin{array}{c}\text { Periode Jam } \\
\text { Puncak }\end{array}$}} & \multicolumn{3}{|c|}{ Tarikan } & \multicolumn{3}{|c|}{ Bangkitan } & \multirow{2}{*}{ TOTAL } & \multicolumn{3}{|c|}{ Tarikan } & \multicolumn{3}{|c|}{ Bangkitan } & \multirow{2}{*}{ TOTAL } \\
\hline & & & MC & $\mathbf{L V}$ & HV & MC & $\mathbf{L V}$ & HV & & MC & $\mathbf{L V}$ & HV & MC & $\mathbf{L V}$ & HV & \\
\hline 9:00 & - & $10: 00$ & 8 & 5 & 1 & 11 & 6 & 4 & 35 & 12 & 11 & 2 & 4 & 12 & 2 & 43 \\
\hline $13: 00$ & - & $14: 00$ & 9 & 4 & 3 & 28 & 18 & 4 & 66 & 15 & 17 & 4 & 15 & 30 & 5 & 86 \\
\hline $16: 00$ & - & $17: 00$ & 16 & 25 & 0 & 14 & 19 & 0 & 74 & 14 & 17 & 0 & 12 & 17 & 0 & 60 \\
\hline 18:00 & - & $19: 00$ & 15 & 19 & 0 & 20 & 25 & 0 & 79 & 4 & 11 & 0 & 18 & 24 & 0 & 57 \\
\hline
\end{tabular}

Tabel 5. Bangkitan dan Tarikan Convention Hall Tanrise City Jember

\begin{tabular}{|c|c|c|c|c|c|c|c|}
\hline \multirow{2}{*}{\multicolumn{3}{|c|}{$\begin{array}{l}\text { Periode Jam } \\
\text { Puncak }\end{array}$}} & \multicolumn{2}{|c|}{ Tarikan } & \multicolumn{2}{|c|}{ Bangkitan } & \multirow{3}{*}{$\begin{array}{c}\text { TOTAL } \\
33\end{array}$} \\
\hline & & & \multirow{2}{*}{$\begin{array}{c}\text { MC } \\
9\end{array}$} & \multirow{2}{*}{$\begin{array}{r}\mathbf{L V} \\
19\end{array}$} & \multirow{2}{*}{$\begin{array}{c}\text { MC } \\
2\end{array}$} & \multirow{2}{*}{$\begin{array}{c}\mathbf{L V} \\
3\end{array}$} & \\
\hline 16.00 & 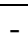 & 17.00 & & & & & \\
\hline 17.00 & - & 18.00 & 10 & 85 & 2 & 15 & 112 \\
\hline 18.00 & - & 19.00 & 10 & 63 & 7 & 18 & 98 \\
\hline 19.00 & - & 20.00 & 8 & 21 & 10 & 126 & 165 \\
\hline
\end{tabular}




\begin{tabular}{ccccccc}
\hline \multirow{2}{*}{$\begin{array}{c}\text { Periode Jam } \\
\text { Puncak }\end{array}$} & \multicolumn{2}{c}{ Tarikan } & \multicolumn{2}{c}{ Bangkitan } & \multirow{2}{*}{ TOTAL } \\
\cline { 2 - 5 } & MC & LV & MC & LV & \\
\hline $20.00-$ & 21.00 & 1 & 5 & 15 & 31 & 52 \\
\hline
\end{tabular}

Tabel 6. Bangkitan dan Tarikan Apartemen Tanrise City Jember

\begin{tabular}{|c|c|c|c|c|c|c|c|c|c|c|c|c|}
\hline \multicolumn{8}{|c|}{ Weekday } & \multicolumn{5}{|c|}{ Weekend } \\
\hline \multirow{2}{*}{\multicolumn{3}{|c|}{$\begin{array}{l}\text { Periode Jam } \\
\text { Puncak }\end{array}$}} & \multicolumn{2}{|c|}{ Tarikan } & \multicolumn{2}{|c|}{ Bangkitan } & \multirow{3}{*}{$\begin{array}{c}\text { TOTAL } \\
45\end{array}$} & \multicolumn{2}{|c|}{ Tarikan } & \multicolumn{2}{|c|}{ Bangkitan } & \multirow{3}{*}{$\begin{array}{c}\text { TOTAI } \\
21\end{array}$} \\
\hline & & & \multirow{2}{*}{$\begin{array}{c}\text { MC } \\
10\end{array}$} & \multirow{2}{*}{$\begin{array}{c}\mathbf{L V} \\
7\end{array}$} & \multirow{2}{*}{$\begin{array}{c}\mathbf{M C} \\
13\end{array}$} & \multirow{2}{*}{$\begin{array}{r}\mathbf{L V} \\
15\end{array}$} & & \multirow{2}{*}{$\begin{array}{c}\text { MC } \\
3\end{array}$} & \multirow{2}{*}{$\begin{array}{r}\mathbf{L V} \\
10\end{array}$} & \multirow{2}{*}{$\frac{\text { MC }}{4}$} & \multirow{2}{*}{$\begin{array}{r}\mathbf{L V} \\
4\end{array}$} & \\
\hline 9:00 & & $10: 00$ & & & & & & & & & & \\
\hline $13: 00$ & - & $14: 00$ & 10 & 8 & 11 & 9 & 38 & 4 & 8 & 4 & 8 & 24 \\
\hline $16: 00$ & - & $17: 00$ & 12 & 17 & 11 & 11 & 51 & 4 & 24 & 14 & 8 & 50 \\
\hline
\end{tabular}

Tabel 1 sampai dengan tabel 6 merupakan hasil perhitungan terhadap bangkitan dan tarikan kendaraan pada masing-masing bangunan di kawasan Tanrise City Jember yang dijadikan sebagai objek penelitian. Tabel 1 sampai dengan tabel 6 memperlihatkan data berupa empat jam puncak kecuali untuk ruko dan apartemen yang hanya terdapat 3 jam puncak. Bangkitan tarikan maksimum yang terjadi pada hotel di tabel 1 adalah sebanyak 265 kendaraan per jam, untuk mall di tabel 2 adalah 108 kendaraan, kemudian ruko di tabel 3 adalah 48 kendaraan, depo bangunan pada tabel 4 adalah 86 kendaraan, convention hall di tabel 5 adalah 118 kendaraan, dan apartemen pada tabel 6 adalah 50 kendaraan. Rata-rata jumlah maksimum bangkitan dan tarikan kendaraan terjadi pada akhir pekan (weekend).

\subsection{Kinerja Parkir}

Perhitungan terhadap kinerja parkir meliputi akumulasi parkir, kapasitas parkir dan indeks parkir

\section{a. Akumulasi parkir}

Penentuan akumulasi parkir diketahui berdasarkan perhitungan jumlah kendaraan masuk dikurangi dengan kendaraan keluar kemudian ditambahkan dengan jumlah kendaraan yang telah terparkir pada lokasi sebelum waktu survei berlangsung. Hasil perhitungan akumulasi parkir berupa grafik sebagai berikut.

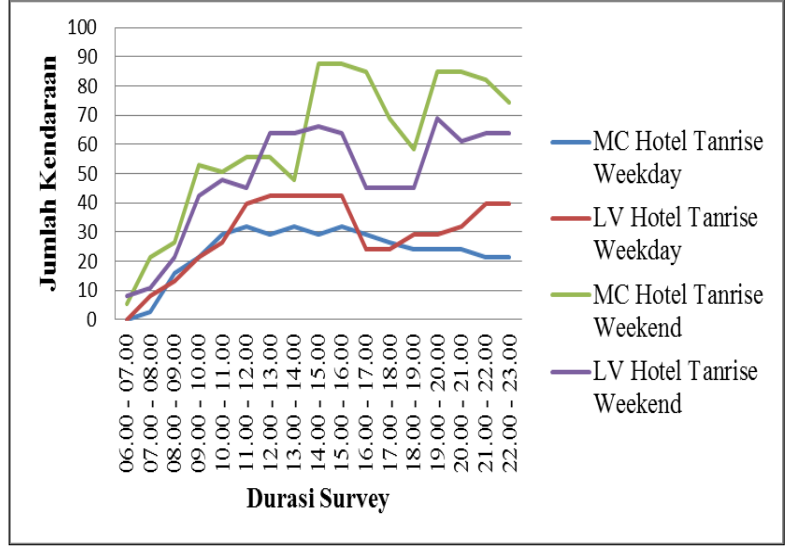

Grafik 3. Akumulasi Parkir Hotel Tanrise City Jember

Grafik 1 menunjukkan adanya kenaikan serta penurunan terhadap jumlah kendaraan dalam durasi waktu tertentu. Pada hari kerja dan akhir pekan rata-rata kenaikan jumlah kendaraan terjadi pada pukul 06.00 - 15.00 yang kemudian mengalami penurunan serta kenaikan jumlah kendaraan.

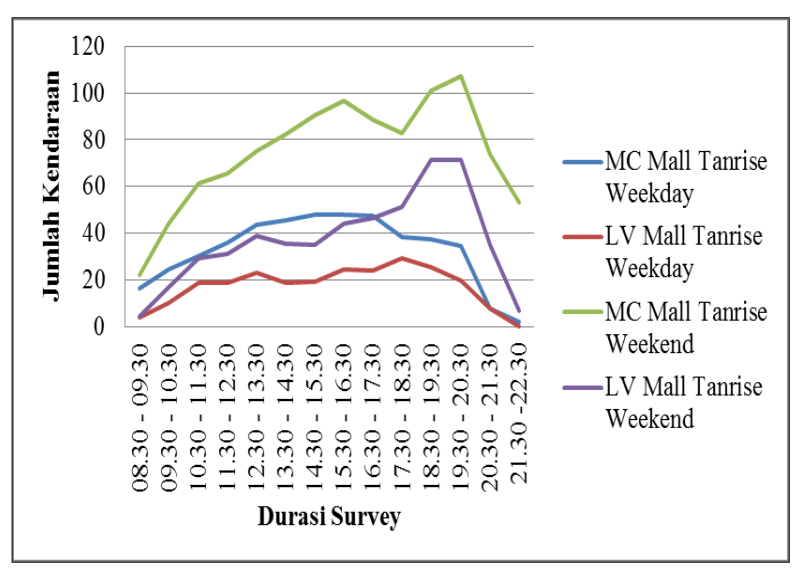

Grafik 2. Akumulasi Parkir Mall Tanrise City Jember

Kemudian grafik 2 menunjukkan akumulasi parkir mall Tanrise City Jember yang mengalami kenaikan serta penurunan jumlah kendaraan pada 
beberapa waktu tertentu. Rata-rata jumlah kendaraan mengalami kenaikan dari pukul 08.30 15.30, untuk MC di hari kerja mengalami penurunan setelah pukul 15.30 - 18.30 dan kembali mengalami kenaikan jumlah kendaraan hingga pukul 20.30. berbeda dengan LV dihari kerja dari pukul 15.30 masih mengalami kenaikan hingga pukul 20.30 kemudian mengalami penurunan jumlah kendaraan. MC dan LV pada akhir pekan mengalami kenaikan jumlah kendaraan hingga pukul 18.30 dan selanjutnya mengalami penurunan jumlah kendaraan.

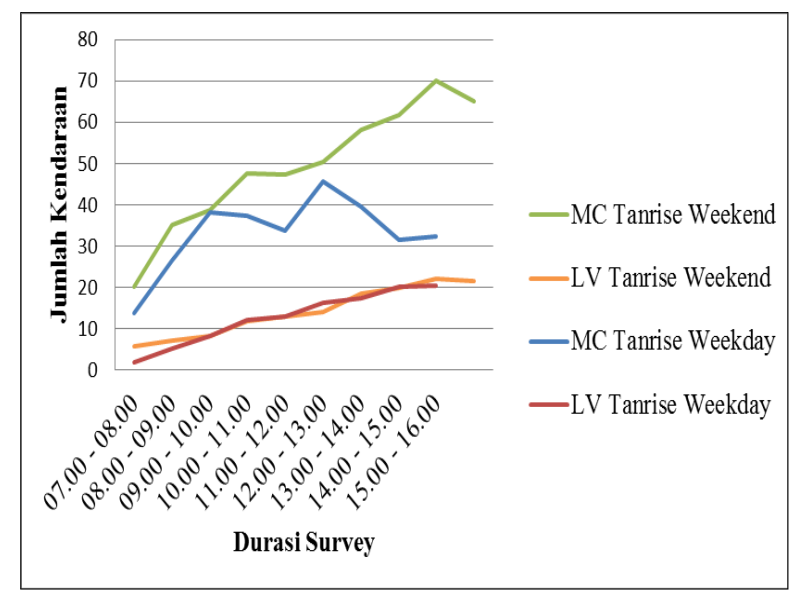

Grafik 3. Akumulasi Parkir Ruko Tanrise City Jember

Grafik 3 menunjukkan bahwa akumulasi parkir pada ruko Tanrise City Jember untuk MC dan LV di akhir pekan terus mengalami kenaikan jumlah kendaraan dari pukul 07.00 - 16.00, sedangkan pada hari kerja mengalami kenaikan dan penurunan jumlah kendaraan. MC di hari kerja mengalami kenaikan dari pukul $07.00-15.00$ kemudian mengalami penurunan jumlah kendaraan,berbeda dengan LV di hari kerja mengalami kenaikan jumlah kendaraan pukul 07.00 - 13.00 kemudian mengalami penurunan jumlah kendaraan.

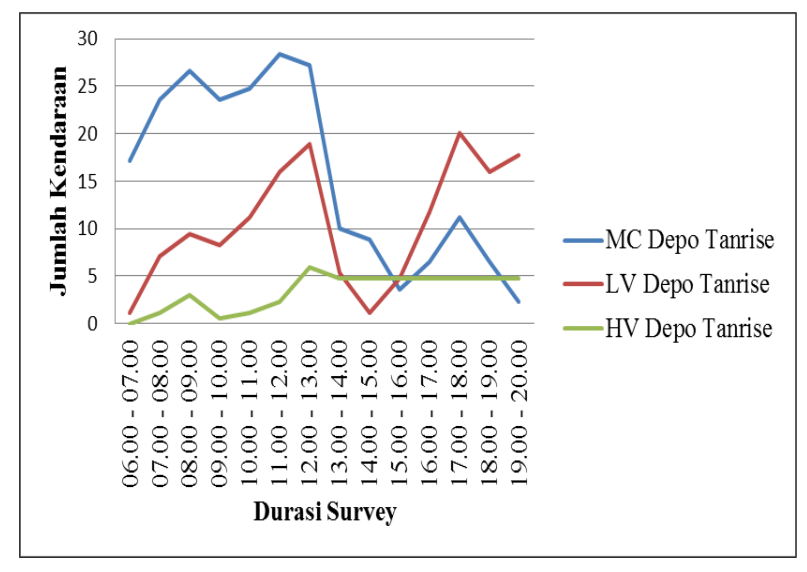

Grafik 4. Akumulasi Parkir Depo Bangunan Tanrise City Jember
Grafik 4 menunjukkan akumulasi parkir pada depo bangunan Tanrise City Jember. grafik MC menunjukkan adanya kenaikan jumlah kendaraan dari pukul $06.00-12.00$ yang kemudian mengalami penurunan hingga pukul 16.00 dan kembali mengalami kenaikan hingga pukul 17.00, selanjutnya mengalami penurunan jumlah kendaraan. Grafik LV menunjukkan adanya kenaikan jumlah kendaraan pukul 06.00 - 13.00, kemudian mengalami penurunan hingga pukul 15.00 dan kembali mengalami kenaikan hingga pukul 18.00. grafik HV menunjukkan kenaikan hingga pukul 09.00, setelah itu mengalami penurunan hingga pukul 10.00 dan mengalami kenaikan kembali hingga pukul 20.00.

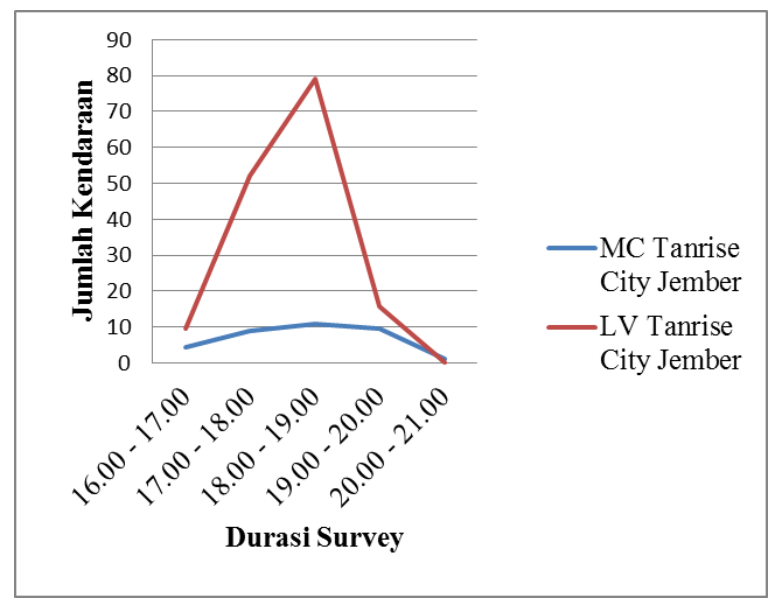

Grafik 5. Akumulasi Parkir Convention Hall Tanrise City Jember

Berdasarkan grafik 5 dapat diketahui akumulasi parkir pada convention hall Tanrise City Jember. Grafik MC menunjukkan adanya kenaikan jumlah kendaraan pada pukul 16.00 - 18.00, kemudian mengalami penurunan hingga pukul 21.00. Grafik LV menunjukkan kenaikan jumlah kendaraan pada pukul $16.00-18.00$ dan mengalami penurunan hingga pukul 21.00 WIB.

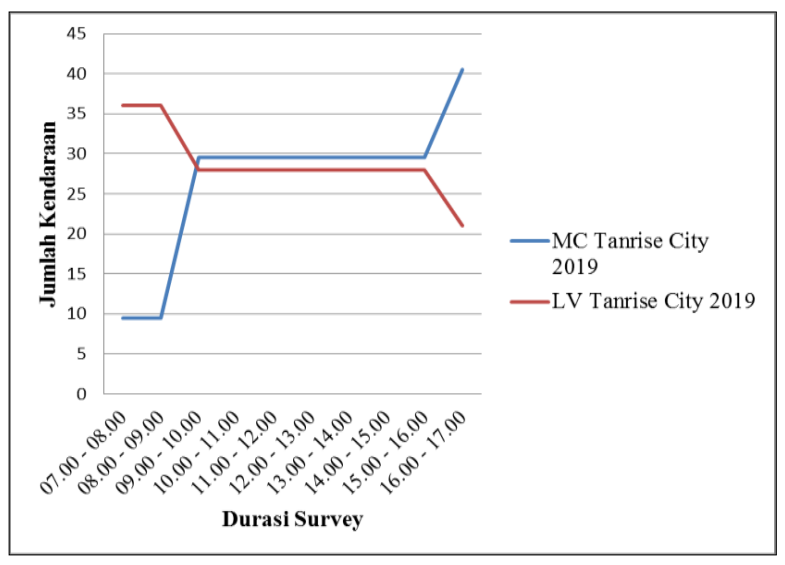

Grafik 6. Akumulasi Parkir Apartemen Tanrise City Jember

Grafik 6 menunjukkan akumulasi parkir pada apartemen Tanrise City Jember. pada grafik dapat 
diketahui bahwa MC mengalami penurunan jumlah kendaraan selama survei berlangsung pada pukul 07.00 - 17.00, sedangkan untuk LV terus mengalami kenaikan jumlah kendaraan dari pukul $07.00-17.00$.

\section{b. Kapasitas parkir}

Kemudian kapasitas parkir merupakan jumlah maksimum kendaraan yang dapat diparkir pada suatu area parkir dalam waktu serta kondisi tertentu. Penentuan kapasitas parkir pada Tanrise City Jember berpacu pada peraturan Pedoman teknis penyelenggaraan fasilitas parkir sesuai dengan SRP kemudian dibandingkan dengan luas lahan parkir yang tersedia. Berikut merupakan hasil perencanaan kapasitas parkir kawasan Tanrise City Jember.

Tabel 7. Kapasitas Parkir Kondisi Perencanaan Tanrise City Jember

\begin{tabular}{llccc}
\hline \multirow{2}{*}{ No } & \multirow{2}{*}{ Bangunan } & \multicolumn{3}{c}{ Lots Parkir } \\
\cline { 3 - 5 } & & MC & LV & HV \\
\hline 1 & Hotel & 98 & 90 & - \\
2 & Convention Hall & 98 & 90 & - \\
3 & Ruko & 63 & 21 & - \\
4 & Mall & 108 & 67 & - \\
5 & Depo Bangunan & 38 & 59 & 6 \\
6 & Apartemen & 42 & 81 & - \\
\hline
\end{tabular}

\section{c. Indeks parkir}

Perhitungan indeks parkir dilakukan untuk mengetahui kemampuan jumlah ruang parkir yang tersedia untuk memenuhi permintaan parkir. terdapat tiga kriteria dalam indeks parkir, yaitu IP $<1$ artinya ruang parkir yang tersedia lebih kecil dari permintaan parkir, IP $=1$ artinya ruang parkir yang tersedia sama dengan jumlah permintaan parkir, IP > 1 artinya ruang parkir yang tersedia lebih kecil dari permintaan parkir. berdasarkan hasil perhitungan terdapat dua hasil berbeda yaitu tiga bangunan dengan IP $<1$ (hotel, depo bangunan, convention hall dan apartemen) dan tiga bangunan dengan IP > 1 (mall dan ruko).

\subsection{Rekomendasi Hasil Perhitungan}

Manajemen parkir dilakukan untuk mengoptimalkan ruang parkir yang tersedia atau memberikan rekomendasi terhadap ruang parkir yang tidak mampu memenuhi permintaan parkir. terdapat dua rekomendasi dalam memanajemen parkir yaitu; melakukan penataan ulang terhadap model ruang parkir dan pengalihan ruang parkir sementara pada waktu tertentu.
Setelah dilakukan manajemen parkir berupa penataan model ruang parkir, terdapat dua bangunan yang masih tidak mampu dalam memenuhi permintaan parkir yaitu mall dan ruko. Maka dilakukan manajemen parkir kedua yaitu dengan melakukan pengalihan ruang parkir sementara. Pengalihan ruang parkir ini dilakukan pada area parkir terdekat dengan bangunan yang ditinjau, untuk mall dialihkan pada area parkir apartemen di basement, parkir ruko dialihkan pada depo bangunan.

\section{Kesimpulan}

Berdasarkan hasil dan pembahasan dapat diperoleh kesimpulan yaitu data bangkitan tarikan maksimum kendaraan masing-masing bangunan untuk hotel 262 kendaraan, mall 120 kendaraan, ruko 48 kendaraan, depo bangunan 86 kendaraan, convention hall 118 kendaraan Dan apartemen 51 kendaraan. Rata-rata kendaraan terbanyak pada Weekend. Kemudian perhitungan perencanaan kapasitas parkir hotel 98 lots roda dua dan 89 lots roda empat; mall 42 lots roda dua dan 81 lots roda empat; ruko 63 lots roda dua dan 21 lots roda empat; depo bangunan 38 lots roda dua, 57 lots roda empat, dan 6 lots kendaraan berat; apartemen 42 lots roda dua dan 81 lots roda empat. Selanjutnya, Evaluasi perhitungan terhadap indeks parkir, rata-rata tiap bangunan yang ditinjau telah memenuhi permintaan kebutuhan ruang parkir yaitu IP $<1$. Namun, pada convention hall, mall dan ruko terdapat IP $>1$ yang artinya tidak mampu memenuhi permintaan parkir.

Sebuah rekomendasi diberikan berdasarkan hasil evaluasi terhadap perencanaan kapasitas parkir pada beberapa bangunan dengan IP $>1$ atau ruang parkir yang tidak mampu memenuhi permintaan parkir adalah dengan melakukan pengalihan ruang parkir.

\section{DAFTAR PUSTAKA}

Direktorat Jenderal Perhubungan Darat.1996. Pedoman teknis penyelenggaraan fasilitas parkir. Jakarta : Direktorat Jenderal Perhubungan Darat

Gallivan, S., 2011, ibm global parking survey: drivers share worldwide parking woes. IBM, 18 September 2011

Lei, Chao dan Yanfeng Ouyang. 2017. "Dynamic pricing and reservation for intelligent urban parking management." Transportation Research Part C: Emerging Technologies 77:226-44.

Pel, Adam J. dan Emmanouil Chaniotakis. 2017. "Stochastic user equilibrium traffic assignment with equilibrated parking search routes." Transportation Research Part B: Methodological 101:123-39. 
Rusmin, M. (2018). Analisis Kinerja Di Simpang Empat Tak Sebidang Kota Makassar Berbasis Mikrosimulasi.

Rusmin, M. (2019). Analisa Kapasitas Dan Kinerja Persimpangan Tak Bersinyal R.A. Kartini. Rancang Bangun, 29-34.

SHAO, Chunfu, Yi ZHAO, Lei YU, dan Juan XU. 2008. "Case Analysis on Vehicle Parking and Departure Plans for the National Stadium." Journal of Transportation Systems Engineering and Information Technology 8(6):52-55.

Zips, Patrik, Martin Böck, dan Andreas Kugi. 2016. "Optimisation based path planning for car parking in narrow environments." Robotics and Autonomous Systems 79:1-11. 